Note

\title{
Effect of Cabergoline, a Dopamine Agonist, on Estrogen-Induced Rat Pituitary Tumors: In Vitro Culture Studies
}

\author{
Kuniki EGUCHI, KeIICHI KAWAMOTO, TOHru UOZUMI, AKIHIRO ITO*, \\ KAZUNORI ARITA, AND KAORU KURISU \\ Department of Neurosurgery, School of Medicine and *Department of Cancer Research, \\ Research Institute for Nuclear Medicine and Biology, Hiroshima University, Hiroshima 734, Japan
}

\begin{abstract}
Cabergoline (CG) is a dopamine agonist that inhibits secretion of prolactin (PRL) and growth hormone. The purpose of this study was to investigate the PRL-lowering effect and antitumor effect of CG on estradiol-induced rat pituitary tumors in vitro and to elucidate these mechanisms. We compared the effects of CG with those of bromocriptine (BC) in terms of the inhibition of hormone secretion as well as antitumor effects on rat pituitary tumors. Primary cultures of dissociated pituitary tumor cells were used in these studies. A significant inhibition of prolactin (PRL) secretion was observed for both drugs within $12 \mathrm{~h}$ after treatment, and the inhibitory effects of CG and BC were antagonized by sulpiride or haloperidol. Inhibitory effect on PRL secretion after 12-h BC or CG pretreatment was more pronounced with CG than BC treatment at all time points. PRL secretion in group pretreated with CG was significantly suppressed at $72 \mathrm{~h}$ when compared to that of vehicle. Inhibition of de novo PRL synthesis was better demonstrated in the CG group. These findings suggest that CG has a higher affinity for the $\mathrm{D}_{2}$ receptor of pituitary cells as compared to $\mathrm{BC}$ and may preferentially inhibit PRL secretion rather than PRL production. An antitumor effect of CG has been confirmed at a lower dosage than that of BC.
\end{abstract}

Key words: Cabergoline, Bromocriptine, Rat pituitary tumor, Prolactinoma, Prolactin

(Endocrine Journal 42: 413-420, 1995)

THE TREATMENT of hyperprolactinemic disorders has been greatly improved since the advent of dopamine agonists. Bromocriptine (BC), an ergot derivative that is now in common clinical use, has a potent prolactin (PRL)-lowering effect [1-3] and an antitumor effect [3, 4-11]. However, BC requires administration several times daily and is not always well tolerated. Recent work in this field has been directed towards the search for drugs with more sustained action that could be given less frequently to patients and therefore improve compliance. On that basis cabergoline (CG) 1-[(6allylergoline-8 $\beta$-yl) carbonyl]-1-[3-(dimethylamino)

Received: September 1, 1994

Accepted: December 16, 1994

Correspondence to: Dr. Kuniki EGUCHI, Department of Neurosurgery, Hiroshima University School of Medicine, 1-2-3 Kasumi, Minami-ku, Hiroshima 734, Japan propyl]-3-ethylurea, an ergot derived compound with long lasting dopamine agonist effects, was developed [2, 3, 12-17]. However, little has been known about the action mechanism of CG on pituitary tumor, such as tumor shrinkage, cytocidal effect and PRL-lowering effect. We have already examined in detail the in vivo effects of CG on estrogen $\left(E_{2}\right)$-induced rat pituitary tumor [18]. The continued oral administration of CG significantly reduced both the serum PRL level and the weight of the pituitary during 15 to 60 days of treatment as compared with BC. Morphologic studies revealed that $C G$ reduced the size of the cells and of the granules, and increased the number of granules per unit cytoplasmic area [18]. The purpose of this study was to clarify the time-related changes and the mechanism of the PRL-lowering and antitumor effect of CG and BC on cultured $E_{2}$-in- 
duced rat pituitary tumors in vitro.

\section{Materials and Methods}

\section{Induction of rat pituitary tumor}

Female F344 rats (Charles River Japan Co., Ltd., Yokohama, Japan) at 4 weeks of age were used in all experiments. The rats were housed under controlled conditions $\left(24{ }^{\circ} \mathrm{C}\right.$ and artificial light from 0600 to $2000 \mathrm{~h}$ ). A pituitary tumor was induced in each rat by subcutaneous implantation of a cholesterol pellet containing $20 \mathrm{mg}$ estradiol- $17 \beta\left(\mathrm{E}_{2}\right)$ for 9 to 10 weeks. Such treatment increased pituitary weight to $96.7 \pm 21.0 \mathrm{mg}$ (mean \pm SEM) and the percentage of PRL cells to $78.5 \pm 2.2 \%$.

\section{Monolayer culture of rat pituitary tumor}

While under ether anesthesia the rats were killed by decapitation and the enlarged pituitary tumor was isolated aseptically. The tumors were minced and incubated with $0.4 \%$ collagenase in phosphate buffered saline (PBS, pH 7.4) for $40 \mathrm{~min}$ at $37^{\circ} \mathrm{C}$ with gentle shaking as previously described [19]. The monodispersed cell suspension in Ham's F 12 containing $10 \%$ fetal bovine serum was placed into $35 \mathrm{~mm}$ culture dishes at a density of $4-6 \times 10^{5}$ cells/dish. The culture dishes were incubated at $37{ }^{\circ} \mathrm{C}$ in an atmosphere of $95 \%$ air and $5 \% \mathrm{CO}_{2}$. To determine optimal preincubation period for the best cultured tumor cell condition, pituitary tumor cells were incubated with vehicle, media with $10^{-7}$ $\mathrm{M}$ dopamine or with $10^{-7}-\mathrm{M}$ thyrotropin releasing hormone for 6 h on day 1, 3, 6, 9 and 12 of primary culture. PRL secretion of cultured tumor cells showed good response to thyrotropin releasing hormone or dopamine treatment after 3 days of the primary culture. Consequently, experimental studies were started on day 3 of culture.

\section{Reagents}

CG was kindly provided by Farmitalia Carlo Erba (Milan, Italy). Estradiol-17 $\beta, \mathrm{BC}$, and sulpiride were purchased from Sigma Chemical Co. (St. Louis, MO). Haloperidol was obtained from Wako Pure Chemical Industries Ltd. (Osaka, Japan). CG and $\mathrm{BC}$ were dissolved in ethanol and further diluted with culture medium. The final concentration of ethanol was $0.04 \%$ in experimental media and controls. Cultured cells were treated with CG and $\mathrm{BC}$ at the concentrations of $10^{-5}, 10^{-7}$ and $10^{-9}$ M.

\section{Inhibitory effect on PRL secretion}

Quadruplicate cultures were used for each experimental group. One hour prior to the beginning of an experiment, one $\mathrm{ml}$ of fresh medium was replaced and the cultures incubated. The medium was then removed and the cells were further incubated for $3,6,12,24,48$, or $72 \mathrm{~h}$ in one $\mathrm{ml}$ of fresh medium with or without reagents at the concentrations noted above. Media were changed every $24 \mathrm{~h}$. Sampled media were and centrifuged $125 \times \mathrm{g}$ at $4^{\circ} \mathrm{C}$ for $10 \mathrm{~min}$ to remove cell debris. Collected supernatants were frozen for radioimmunoassay. To elucidate the mechanism involved in the inhibition of PRL secretion by dopamine agonist, cultured cells were co-incubated with CG or $\mathrm{BC}$ and sulpiride, a selective $\mathrm{D}_{2}$ antagonist, or haloperidol, a nonselective dopaminergic antagonist. The cells were treated for $3 \mathrm{~h}$ in one $\mathrm{ml}$ of medium with or without the following substances: $10^{-7} \mathrm{M}$ CG, $10^{-7} \mathrm{M} \mathrm{BC}, 10^{-4} \mathrm{M}$ sulpiride and $10^{-6} \mathrm{M}$ haloperidol. After treatment media were collected and stored as described above.

\section{Recovery of PRL secretion after withdrawal of D2 agonist}

After $12 \mathrm{~h}$ pre-incubation with cabergoline or bromocriptine, cultured cells were rinsed twice with fresh medium and subsequently cultured in medium without a dopamine agonist for an additional $12 \mathrm{~h}$. The medium was collected and stored as above.

\section{PRL assay}

PRL was measured by radioimmunoassay (RIA) using a double antibody method. The PRL standards (NIDDK rat PRL RP-3, AFP-4459B) were provided by the National Institute of Diabetes, Digestive and Kidney Diseases (NIDDK Bethesda, MD) and the anti-rat PRL serum (HAC-RT2601RBP85) by Dr. Wakabayashi (Institute for Molecular \& Cellular Regulation, Gunma University, Maebashi, Japan). Radioiodinated rat PRL and goat anti-rabbit IgG were purchased from Du Pont/ 
NEN Research Products (Boston, MA) and Bio Makor (Rehovot, Israel), respectively.

\section{Analysis of de novo synthesis of PRL}

Monodispersed cells at a density of $6 \times 10^{5}$ cells / dish were precultured for 3 days. Culture media were replaced with leucine-free Eagle's minimum essential medium (MEM) (Nissui Pharma Co., Tokyo, Japan) supplemented with $10 \mu \mathrm{Ci} / \mathrm{ml}$ of $\left[{ }^{3} \mathrm{H}\right]$ L-leucine (Du Pont/NEN Research Products, Boston, MA). After a three to $24 \mathrm{~h}$ incubation the dishes were rinsed with PBS and frozen at -20 ${ }^{\circ} \mathrm{C}$. The thawed cells were scraped from the dish and homogenized by sonication in ice-cold PBS. The samples were diluted 1:4 with PBS containing $1 \%$ bovine serum albumin (BSA-PBS), mixed with $100 \mu l$ of a 1:400 dilution of anti-rat PRL serum (HAC-RT26-01RBP85) in PBS containing $50 \mathrm{mM}$ EDTA and $0.5 \%$ normal rabbit serum, and further incubated at room temperature for $24 \mathrm{~h}$. The antibody-bound rat PRL was incubated for $12 \mathrm{~h}$ after addition of goat anti-rabbit IgG dissolved in $400 \mu \mathrm{l}$ of PBS containing $50 \mathrm{mM}$ EDTA, 3.5\% polyethylene glycol (EDTA-PBS) and $100 \mu$ of BSA-PBS. The mixture was centrifuged at $1500 \times \mathrm{g}$ for $20 \mathrm{~min}$ at 4 ${ }^{\circ} \mathrm{C}$. The precipitate was washed twice with EDTAPBS containing $0.25 \%$ Triton X-100, dissolved in $250 \mu l$ of $0.5 \mathrm{~N} \mathrm{NaOH}$ and neutralized with $250 \mu l$ of $0.5 \mathrm{~N} \mathrm{HCl}$. A $200 \mu l$ aliquot was mixed with 10 $\mathrm{ml}$ of scintillation fluid (Clear-sol I; Nacalai Tesque Inc., Kyoto, Japan). The radioactivity in samples was measured in duplicate in a liquid scintillation counter (LSC-3500, Aloka, Tokyo, Japan). Specific counts were calculated from the difference between total count and nonspecific count (14250 dpm).

\section{MTT assay}

MTT assay was performed using previously described techniques [20]. The monodispersed cell suspension $(0.5 \mathrm{ml})$ was placed into a 24 -well dish at a density of $1.0 \times 10^{5}$ cells/well. Cultured tumor cells were treated with BC or CG at $10^{-5}, 10^{-7}, 10^{-9}$ $\mathrm{M}$ from day 3 of culture. Culture medium with or without reagents was changed every $24 \mathrm{~h}$.

For the MTT assay, media were replaced with $500 \mu l$ of PBS containing $0.1 \%$ sodium succinate and $0.4 \%$ 3-(4, 5-dimethylthiazol-2-yl)-2, 5-diphenyl tetrazolium bromide (MTT) and incubated for $3 \mathrm{~h}$ at $37^{\circ} \mathrm{C}$ in a $\mathrm{CO}_{2}$ incubator. After incubation the MTT solution was aspirated and MTT formazan was dissolved with $500 \mu l$ of dimethyl sulfoxide. A $100 \mu l$ aliquot was transferred in duplicate into a 96-well microplate and optical density (OD) was measured with a microplate reader (EAR340AT, SLT Labinstrument, Co., Ltd., Austria) with a test wavelength of $570 \mathrm{~nm}$ and a reference wavelength of $620 \mathrm{~nm}$. Linearity in OD of the MTT assay under our experimental conditions occurred at $2.3 \times 10^{4}$ to $7.0 \times 10^{5}$ cells $/$ well and the values in every experimental group were within the linear range.

\section{Statistical method}

Data were reported as the mean \pm SEM. Differences between two groups were statistically analyzed by Mann-Whitney $U$ test. A level of $P$ less than 0.05 was accepted as statistically significant.

\section{Results}

\section{PRL secretion from cultured pituitary cells}

Pituitary tumor cells showed higher basal PRL values on day 3 and 6 of primary culture and showed the best response of PRL secretion to thyrotropin releasing hormone or dopamine treatment on day 3. Experimental studies were therefore started on day 3 of culture.

$B C$ and CG did not significantly decrease PRL secretion at any concentration within the first $3 \mathrm{~h}$ of treatment. The inhibitory effect of these reagents on PRL secretion began to appear at $6 \mathrm{~h}$ after treatment, and after $12 \mathrm{~h}$ a significant decrease in PRL secretion was detected at all concentrations of both agents (Fig. 1). These inhibitory effects became to be almost constant at $24 \mathrm{~h}$ after treatment. Although dose-dependent inhibition was observed in groups treated with $\mathrm{BC}$, no difference in the inhibitory effect at the highest concentration $\left(10^{-5}\right.$ M) was evident between BC and CG. In contrast, the effect at the lower concentrations $\left(10^{-7} \mathrm{M}\right.$ and $10^{-6} \mathrm{M}$ ) was more pronounced with CG than $\mathrm{BC}$ (Fig. 1).

The inhibitory effect of CG and BC at the same concentration was antagonized by concomitant treatment with $10^{-4} \mathrm{M}$ sulpiride or $10^{-6} \mathrm{M}$ haloperidol (Fig. 2). Also, sulpiride stimulated PRL 


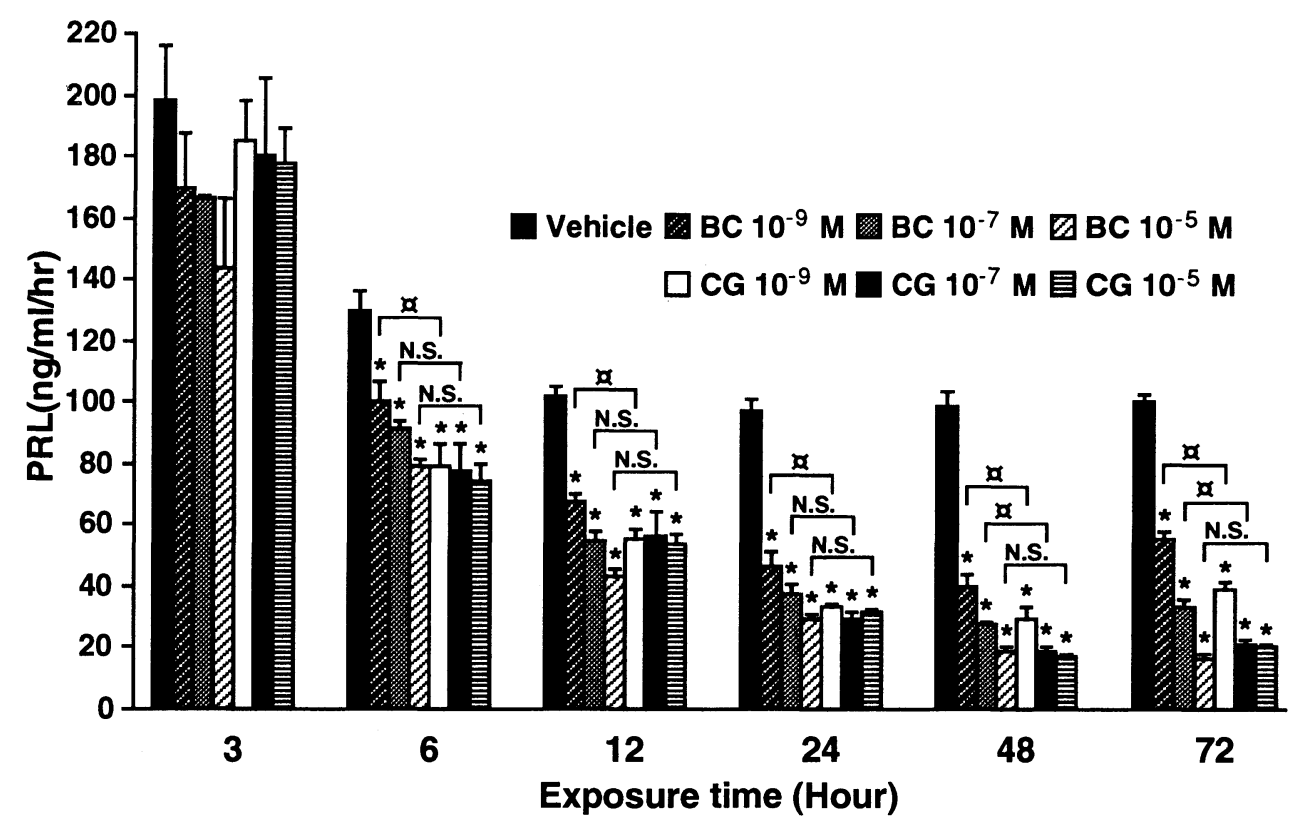

Fig. 1. Inhibitory effect of bromocriptine (BC) and cabergoline (CG) on prolactin (PRL) secretion. No statistically significant difference at the $P<0.05$ level between any groups treated for 3 h. ${ }^{*} P<0.05$ vs. comparable vehicle, $\boldsymbol{a} P<0.05$. N.S., not significant.

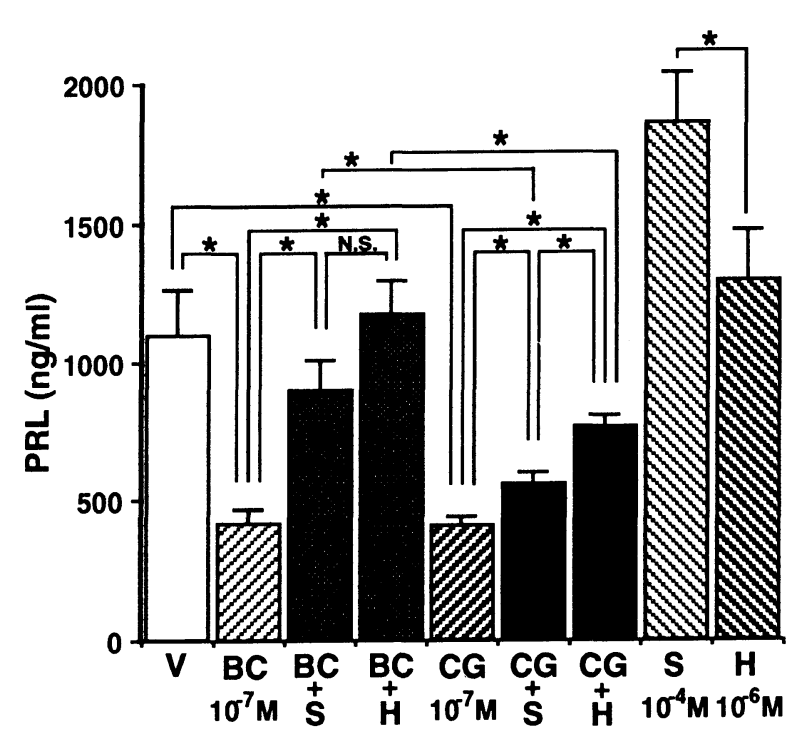

Fig. 2. Effects of the dopamine $\left(\mathrm{D}_{2}\right)$ antagonists sulpiride (S) and haloperidol $(\mathrm{H})$ on inhibition of prolactin (PRL) secretion. Inhibitory effect of $10^{-7} \mathrm{M} \mathrm{BC}$ or $\mathrm{CG}$ was antagonized by a $3 \mathrm{~h}$ co-incubation with $10^{-4} \mathrm{M}$ sulpiride (S) or $10^{-6} \mathrm{M}$ haloperidol $(\mathrm{H}) .{ }^{*} \mathrm{P}<0.05$. N.S., not significant; $V$, vehicle. secretion, while haloperidol did not. These findings demonstrate that CG also inhibits PRL secretion via $\mathrm{D} 2$ receptors.

\section{Recovery of PRL secretion after withdrawal of $D_{2}$ agonist}

Inhibitory effect on PRL secretion after withdrawal of $\mathrm{D}_{2}$ agonists was more pronounced with CG than $\mathrm{BC}$ treatment at all time points. Although no significant difference between these two groups was detected, PRL secretion in the group pretreated with CG was significantly suppressed at $72 \mathrm{~h}$ when compared to that with vehicle alone (Fig. 3). These results suggest that CG has a higher affinity binding to the $\mathrm{D}_{2}$ receptor of the tumor cells than BC.

Analysis of de novo synthesis of PRL

De novo synthesis of PRL was measured in terms of immunoprecipitable radioactivity of $\left[{ }^{3} \mathrm{H}\right]$ PRL per dish. Both CG and BC suppressed de novo synthesis of PRL within the first $3 \mathrm{~h}$ after treatment. This effect of BC persisted $24 \mathrm{~h}$ after treatment, while CG did not suppress de novo synthesis of PRL in tumor cells after $6 \mathrm{~h}$ of treatment (Fig. 4). 


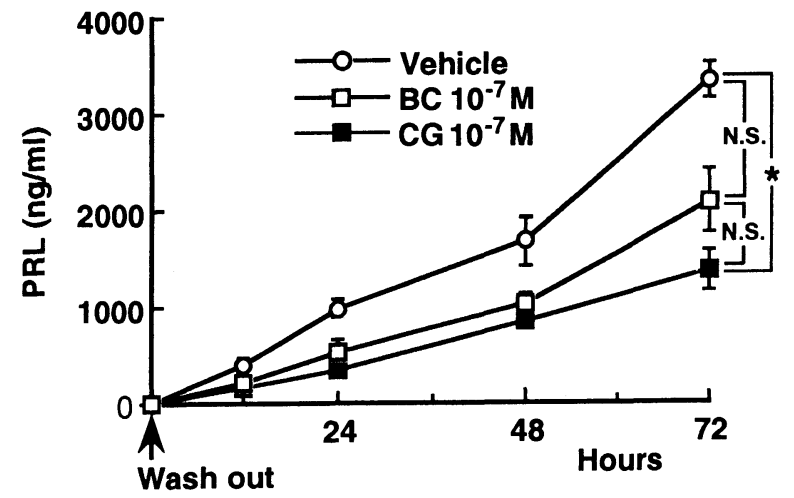

Fig. 3. Recovery of prolactin (PRL) secretion after $12 \mathrm{~h}$ incubation and withdrawal of $10^{-7} \mathrm{M}$ bromocriptine (BC) or cabergoline (CG). ${ }^{*} P<0.05$. N.S., not significant.

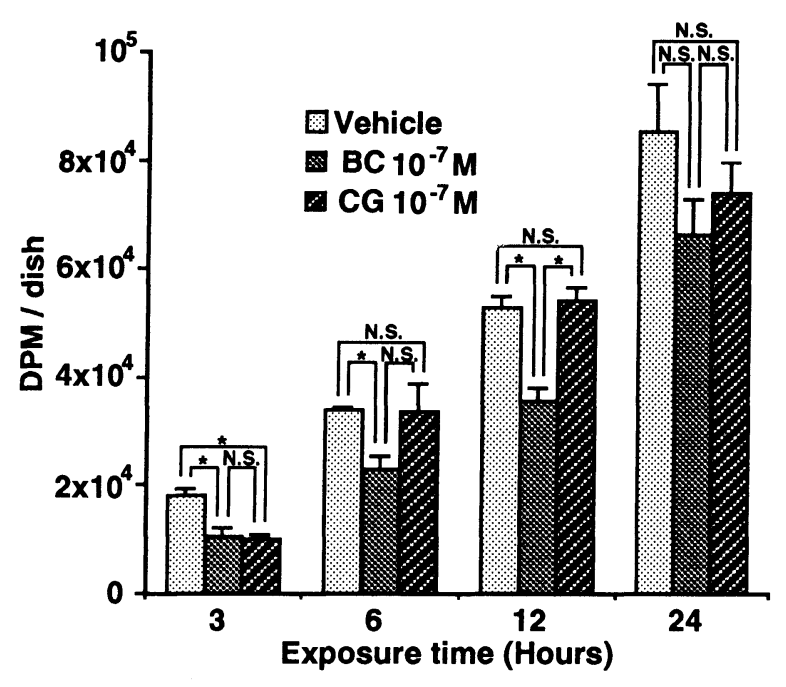

Fig. 4. Effect of bromocriptine (BC) and cabergoline (CG) on de novo synthesis of prolactin (PRL). Ordinate indicates the disintegrations per minutes (DPM) of intracellular [ $\left.{ }^{3} \mathrm{H}\right] \mathrm{PRL} /$ dish. ${ }^{*} P<0.05$. N.S., not significant.

\section{Antitumor effect}

Antitumor effect of $D_{2}$ agonists was evaluated with the MTT assay. In the CG group, an antitumor effect was demonstrated on the 4 th and the 6th day of the treatment at the concentrations of $10^{-5}$ to $10^{-9} \mathrm{M}$ (Fig. 5). BC had an antitumor effect only at the highest concentration after 6 days of treatment. CG had a greater antitumor effect on cultured pituitary tumor cells as compared to BC.

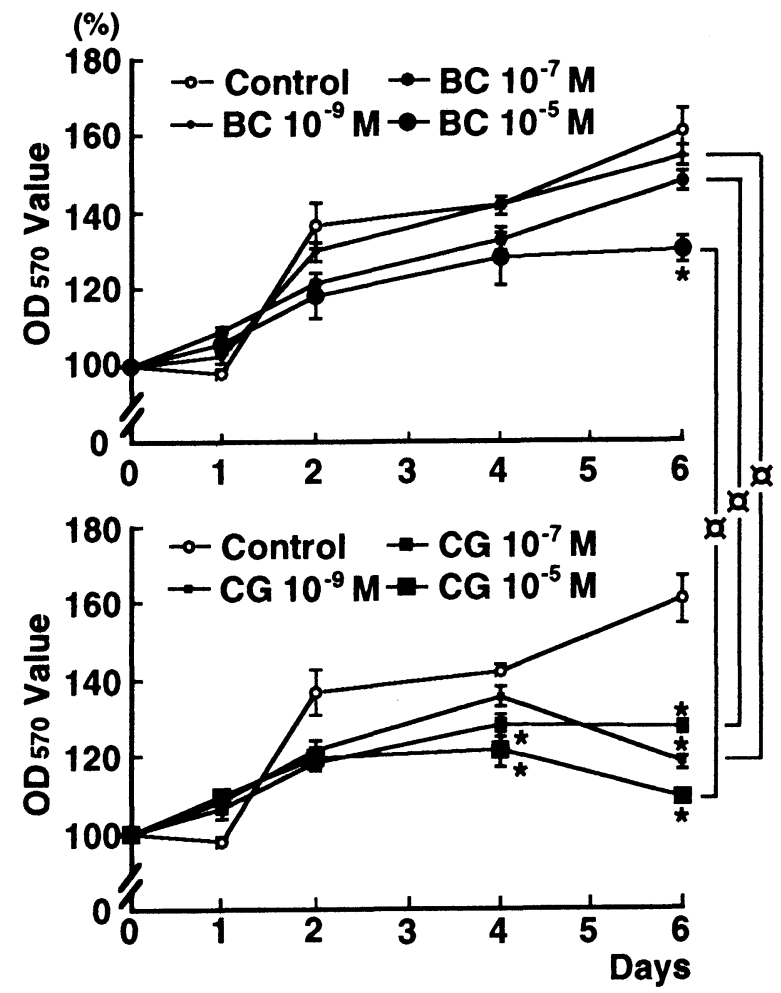

Fig. 5. Antitumor effect of bromocriptine (BC, upper) and of cabergoline ( $C G$, lower) evaluated by chromogenic assay. ${ }^{*} P<0.05$ vs. comparable control, $\boldsymbol{x} P<0.05$.

\section{Discussion}

$\mathrm{BC}$ was the first compound that was effective in the treatment of hyperprolactinemic disorders. Prolonged administration of this agent results in rapid tumor shrinkage $[2,4,9,13,21-23]$. This agent also has a potent PRL-lowering effect and cytocidal effect in in vitro studies of human pituitary adenomas [6, 24-27].

It has been well established that chronic E2 treatment in rats induces PRL-secreting pituitary tumors. Such tumors also possess $\mathrm{D}_{2}$ dopamine receptors similar to those present in normal tissue [28-30]. We have compared the effectiveness of CG and $B C$ by using $E_{2}$-induced rat pituitary tumors as a model for human prolactinomas [18].

In the present study CG had a marked PRL-lowering effect on cultured rat pituitary tumor cells. This effect was equal to that of $\mathrm{BC}$ and is in agree- 
ment with the findings of previous studies $[15,16]$ that utilized rat pituitary cells in vitro. The fact that the PRL-lowering effect of CG, like BC, is blocked by dopamine receptor antagonists demonstrated that this effect is mediated by D2 receptors of lactotrophs. The present study also demonstrated that the inhibitory effect on PRL secretion occurred at lower concentrations of CG than BC. In addition, the recovery of PRL secretion after withdrawal of CG was slower than that of $B C$. These findings suggest that CG has a higher affinity for the D2 receptor of pituitary cells as compared to BC. A previous study has shown that the affinity of CG for dopamine receptors is about twice that of $\mathrm{BC}$ in rat striatal tissue [31].

$B C$ reduces the rate of PRL synthesis, probably as a result of increased intracellular PRL content within lactotrophs. The present results agree well with those of previous studies [9, 32, 33]. In contrast, CG reduced the rate of PRL synthesis within $3 \mathrm{~h}$ of treatment, but thereafter it did not inhibit de novo synthesis of PRL, regardless of continued inhibition of PRL secretion from tumor cells. These findings support our results that the chronic administration of CG increases the number of PRL-immunoreactive secretory granules per unit cytoplasmic area in in vivo study [18]. Although the reason for these differences remains unknown, one possibility is that CG may preferentially inhibit PRL secretion rather than PRL production.

In vitro treatment of adenoma cells with $\mathrm{BC}$ induces numerous intracellular vacuoles, probably originating from dilated rough endoplasmic reticulae $[6,26,34]$, and results in cell death. Such a direct cytocidal effect by $\mathrm{BC}$ is more pronounced on PRL-secreting adenoma cells than on growth hormone-secreting adenoma cells [6]. From immunoelectron microscopic observation, we previously verified that $C G$ induced degenerating PRL tumor cells with vacuolized and fragmented rough endoplasmic reticula in in vivo treatment [18]. In the present study the antitumor effect of CG or $\mathrm{BC}$ on cultured pituitary cells was examined by MTT assay, a quantitative colorimetric assay for mammalian cell cytotoxity and proliferation [20, $35,36]$. The present result confirmed that CG has more potent cytocidal effects against pituitary tumor cells than BC. However, we have not yet tested by the appropriate inhibition studies whether the antitumor effect of CG is mediated by $\mathrm{D}_{2}$ dopamine receptors alone.

The many drugs that have been reported to suppress PRL secretion and shrink prolactinomas include pergolide [5, 37, 38], CV 205-502 [39-43], injectable BC [44], lisuride [22, 45], metergoline [45], terguride [46, 47], dehydroergocriptine [48], mesulergin [49], and CG [2, 3, 12, 13]. Of these drugs pergolide, CV 205-502, an injectable form of BC and CG are reported to be long-acting and will suppress PRL levels for approximately $24 \mathrm{~h}, 24 \mathrm{~h}$, 28 days and 7 days, respectively. Their side effects are similar to those of BC $[22,44,48]$, but CV 205-502 and CG are generally better tolerated than BC $[2,12,13,17,42,43]$.

We were able to demonstrate in vitro that CG has several advantages in terms of PRL-lowering effect and antitumor effect on $\mathrm{E}_{2}$-induced rat pituitary tumors. These advantages might be attributable to a higher affinity for the $\mathrm{D}_{2}$ receptor of pituitary tumor cells and its chemical stability [18] as compared with that of BC.

\section{Acknowledgments}

The authors are grateful to Drs. S. Raiti and T. Taylor, the National Hormone and Pituitary Program, and the National Institute of Diabetes and Digestive and Kidney Diseases (NIDDK), and to Dr. A. F. Parlow, Pituitary Hormones/Antisera Center, Harbor-UCLA Medical Center, for supplying rat PRL. We also thank Dr. Wakabayashi, Gunma University (Maebashi, Japan), for his generous gift of anti-PRL serum. This work was supported in part by a Grant-in-Aid for Scientific Research from the Ministry of Education, Science and Culture of Japan (No. 06454415).

\section{References}

1. Tallo D, Malarkey WB (1981) Adrenergic and dopaminergic modulation of growth hormone and prolactin secretion in normal and tumor-bearing human pituitaries in monolayer culture. J Clin Endocrinol Metab 53: 1278-1284.

2. Cooper PR (1991) Nonoperative management of 
prolactinomas. In: Cooper PR (ed) Contemporary Diagnosis and Management of Pituitary Adenomas. AANS Publications Committee, Illinois, 83-100.

3. Philosophe R, Seibel MM (1991) Novel approaches to the management of hyperprolactinemia. Curr Opin Obstet Gynecol 3: 336-342.

4. Gen M, Uozumi T, Ohta M, Ito A, Kajiwara H, Mori S (1984) Necrotic changes in prolactinomas after long term administration of bromocriptine. J Clin Endocrinol Metab 59: 463-470.

5. Goldstein M, Lieberman A, Lew JY, Asano T, Rosenfeld MR, Makman MH (1980) Interaction of pergolide with central dopaminergic receptors. Proc Natl Acad Sci USA 77: 3725-3728.

6. Kawamoto K, Uozumi T, Sakoda K, Mukada K, Kurisu K, Yano T (1992) Cytocidal effects of bromocriptine, somatostatin analog, and heat on growth hormone-secreting pituitary adenoma in vitro. Cancer 69: 2688-2696.

7. Landolt AM, Minder H, Osterwalder V, Landolt TA (1983) Bromocriptine reduces the size of cells in prolactin secreting-pituitary adenomas. Experientia 39: 625-626.

8. Mori H, Mori S, Saitoh Y, Arita N, Aono T, Uozumi T, Mogami H, Matsumoto K (1985) Effect of bromocriptine on prolactin-secreting pituitary adenomas. Cancer 56: 230-238.

9. Rengachary SS, Tomita T, Jefferies BF, Watanabe I (1982) Structural changes in human pituitary tumor after bromocriptine therapy. Neurosurgery 10: 242-251.

10. Saitoh Y, Koizumi K, Arita N, Hayakawa T, Mogami H, Matsumoto K, Mori H (1986) Antitumor effect of bromocriptine on estrogen-induced rat prolactinomas: ultrastructural alterations of secretory granules. Anticancer Res 6: 1149-1156.

11. Saitoh $Y$, Mori S, Arita N, Hayakawa T, Mogami H, Matsumoto K, Mori H (1986) Cytosuppressive effect of bromocriptine on human prolactinomas: stereological analysis of ultrastructural alterations with special reference to secretory granules. Cancer Res 46: 1507-1512.

12. Ciccarelli E, Giusti M, Miola C, Potenzoni F, Sghedoni D, Camanni F, Giordano G (1989) Effectiveness and tolerability of long term treatment with cabergoline, a new long-lasting ergoline derivative, in hyperprolactinemic patients. J Clin Endocrinol Metab 69: 725-728.

13. Crosignani PG, Ferrari C (1990) Dopaminergic treatments for hyperprolactinemia. Bailliere's Clin Obstet Gynecol 4: 441-455.

14. di Salle E, Ornati G, Briatico G (1982) FCE 21336, a new ergoline derivative with a potent and longacting lowering effect on prolactin secretion in rats. J Endocrinol Invest 5 (Suppl 1): 45 (Abstract).

15. di Salle E, Ornati G, Giudici D, Ragazzi P (1983) Effect of the new ergoline derivative FCE 21336 on prolactin and $\mathrm{LH}$ secretion in the rat. J Endocrinol Invest 6 (Suppl 1): 6 (Abstract).

16. di Salle E, Ornati G, Giudici D (1984) A comparison of the in vivo and in vitro duration of prolactin lowering effect in rats of FCE 21336, pergolide and bromocriptine. J Endocrinol Invest 7 (Suppl 1): 32 (Abstract).

17. Ferrari C, Mattei A, Melis GB, Paracchi A, Muratori M, Faglia, Sghedoni D, Crosignani PG (1989) Cabergoline: long-acting oral treatment of hyperprolactinemic disorders. J Clin Endocrinol Metab 68: 1201-1206.

18. Eguchi K, Kawamoto K, Uozumi T, Ito A, Arita K, Kurisu K (1995) In vivo effect of cabergoline, a dopamine agonist, on estrogen-induced rat pituitary tumors. Endocrine Journal 42: 153-161.

19. Kawamoto K, Uozumi T, Yano T, Arita K, Kurisu K, Kiya K (1992) Lethal effects of the combination of hyperthermia and bromocriptine or a somatostatin analogue on normal pituitary cells and pituitary tumour cells. Int J Hyperthermia 8: 747-754.

20. Matsuda Y, Kawamoto K, Kiya K, Kurisu K, Sugiyama K, Uozumi T (1994) Antitumor effect of antiprogesterones on human meningioma cells in vitro and in vivo. J Neurosurg 80: 527-534.

21. Bassetti M, Spada A, Pezzo G, Giannattasio G (1984) Bromocriptine treatment reduces the cell size in human macroprolactinomas: a morphometric study. J Clin Endocrinol Metab 58: 268-273.

22. Chiodini P, Liuzzi A, Cozzi R, Verde G, Oppizzi G, Dallabonzana D, Spelta B, Silvestrini F, Borghi G, Luccarelli G, Rainer E, Horowski R (1981) Size reduction of macroprolactinomas by bromocriptine or lisuride treatment. I Clin Endocrinol Metab 53: 737-743.

23. Thorner MO, Martin WH, Rogol AD, Morris JL, Perryman RL, Conway BP, Howards SS, Wolfman MG, MacLeod RM (1980) Rapid regression of pituitary prolactinomas during bromocriptine treatment. J Clin Endocrinol Metab 51: 438-445.

24. Adams EF, Brajkovich IE, Mashiter K (1979) Hormone secretion by dispersed cell cultures of human pituitary adenomas. J Clin Endocrinol Metab 49: 120126.

25. Hassoun J, Jaquet $P$, Devictor B, Andonian C, Grisoli F, Gunz G, Toga M (1985) Bromocriptine effects on cultured human prolactin-producing pituitary adenomas: in vitro ultrastructural, morphometric, and immunoelectron microscopic studies. J Clin Endocrinol Metab 61: 686-692.

26. Kabuto M, Kubota T, Hayashi M, Yamamoto S (1985) Cytocidal effect of bromocriptine on human pituitary adenoma cells. Neurol Med Chir (Tokyo) 25: 886-893.

27. Mashiter K, Adams E, Beard M, Holley A (1977) Bromocriptine inhibits prolactin and growth-hormone release by human pituitary tumours in 
culture. Lancet 2: 197-198.

28. Bouvior C, Potier M, Beauregard G, Lafond J, Amlaiky N, Caron MG, Collu R (1986) Solubilization and characterization of D2-dopamine receptors in an estrone-induced, prolactin-secreting rat pituitary adenoma. J Neurochem 47: 1653-1660.

29. Eljarmak D, Marchisio AM, Lis M, Collu R (1985) Presence of high affinity dopamine receptors in estrone-induced, prolactin-secreting rat pituitary adenomas: a model for human prolactinomas. Horm Res 21: 107-116.

30. Eljarmak D, Lis M, Cantin M, Carriere PD, Collu R (1985) Effects of chronic bromocriptine treatment of an estron-induced, prolactin-secreting rat pituitary adenoma. Horm Res 21: 160-167.

31. Benedetti MS, Dostert P, Barone D, Efthymiopoulos C, Peretti G, Roncucci R (1990) In vivo interaction of cabergoline with rat brain dopamine receptors labelled with [ $\left.{ }^{3} \mathrm{H}\right] \mathrm{N}-n$-propylnorapomorphine. Eur J Pharmacol 187: 399-408.

32. Dannies PS, Rudnick MS (1980) 2-bromo- $\alpha$ ergocryptine causes degradation of prolactin in primary cultures of rat pituitary cells after chronic treatment. J Biol Chem 255: 2776-2781.

33. Maurer RA (1980) Dopaminergic inhibition of prolactin synthesis and prolactin messenger RNA accumulation in cultured pituitary cells. J Biol Chem 255: 8092-8097.

34. Anniko M, Werner S, Wersäll J (1981) Bromocriptine-induced changes in hormone secretion and cell morphology in growth hormone and prolactin producing pituitary adenomas. Acta Otolaryngol 92: 343-355.

35. Carmichael J, DeGraff WG, Gazdar AF, Minna JD, Mitchell JB (1987) Evaluation of a tetrazolium-based semiautomated colorimetric assay: assessment of chemosensitivity testing. Cancer Res 47: 936-942.

36. Mosmann T (1983) Rapid colorimetric assay for cellular growth and survival: application to proliferation and cytotoxity assays. J Immunol Methods 65: 55-63.

37. Kleinberg DL, Boyd AE III, Wardlaw S, Frantz AG, George A, Bryan N, Hilal S, Greising J, Hamilton D, Seltzer T, Sommers CJ (1983) Pergolide for the treatment of pituitary tumors secreting prolactin or growth hormone. N Engl J Med 309: 704-709.

38. Wong DT, Bymaster FP, Lane PT, Kau D, Bach NJ, Kornfeld EC (1980) Binding of $\left[{ }^{3} \mathrm{H}\right]$ pergolide mesylate to dopamine receptors of mammalian brains. Res Commun Chem Pathol Pharmacol 30: 195-
210.

39. Khalfallah Y, Claustrat B, Grochowicki M, Flocard F, Horlait S, Serusclat P, Sassolas G (1990) Effects of a new prolactin inhibitor, CV 205-502, in the treatment of human macroprolactinomas. J Clin Endocrinol Metab 71: 354-359.

40. Newman CB, Hurley AM, Kleinberg DL (1989) Effect of CV 205-502 in hyperprolactinaemic patients intolerant of bromocriptine. Clin Endocrinol (Oxf) 31: 391-400.

41. Rasmussen C, Bergh T, Wide L, Brownell J (1987) CV 205-502: a new long-acting drug for inhibition of prolactin hypersecretion. Clin Endocrinol (Oxf) 26: 321-326.

42. Rasmussen C, Bergh T, Wide L, Brownell J (1988) Long-term treatment with a new non-ergot longacting dopamine agonist, CV 205-502, in woman with hyperprolactinaemia. Clin Endocrinol (Oxf) 29: 271-279.

43. Vance ML, Cragun JR, Reimnitz C, Chang RJ, Rashef E, Blackwell RE, Miller MM, Molitch ME (1989) CV 205-502 treatment of hyperprolactinemia. J Clin Endocrinol Metab 68: 336-339.

44. Bronstein MD, Cardim CS, Marino R Jr (1987) Shortterm management of macroprolactinomas with a new injectable form of bromocriptine. Surg Neurol 28: 31-37.

45. Crosignani PG, Ferrari C, Liuzzi A, Benco R, Mattei A, Rampini P, Dellabonzana D, Scarduelli C, Spelta B (1982) Treatment of hyperprolactinemic states with different drugs: a study with bromocriptine, metergoline, and lisuride. Fertil Steril 37: 61-67.

46. Dallabonzana D, Liuzzi A, Oppizzi G, Cozzi R, Verde G, Chiodini P, Rainer E, Dorow R, Horowski R (1986) Chronic treatment of pathological hyperprolactinemia and acromegaly with the new ergot derivative terguride. J Clin Endocrinol Metab 63: 1002-1007.

47. Venturini PL, Horowski R, Valenzano M, Costantini S, Fasce V, Gorlero F, Rainer E, De Cecco L (1986) Effect of tergulide on prolactin levels in normal, puerperal and hyperprolactinaemic women. Eur J Clin Pharmacol 30: 195-197.

48. Faglia G, Conti A, Muratori M, Togni E, Travaglini P, Zanotti A, Mailland F (1987) Dihydroergocriptine in management of microprolactinomas. J Clin Endocrinol Metab 65: 779-784.

49. Grossman A, Besser GM (1985) Prolactinomas. Br Med J 290: 182-184. 